\title{
Kajian Referensi tentang: Biaya Pendidikan Mandiri yang Berorientasi pada Mutu
}

\author{
Aidah Maqbulah \\ STAI Al-Aqidah Al-Hasyimiyyah, Jakarta, Indonesia \\ E-mail: aidahasyim@gmail.com
}

\begin{tabular}{|c|c|}
\hline Article Info & Abstract \\
\hline $\begin{array}{l}\text { Article History } \\
\text { Received: } 2021-07-12 \\
\text { Revised: 2021-08-15 } \\
\text { Published: 2021-09-13 }\end{array}$ & $\begin{array}{l}\text { An advance of an institution can be measured by the quality and the progress of all } \\
\text { units under it. Human resources and human capitals in an organization or an } \\
\text { institution are determined by the quality of it's human resource's education. Therefore, } \\
\text { this institution has the duty of giving an educational system that guarantees to all } \\
\text { citizenship include all human resources who involve in that institution to get a high } \\
\text { quality of education. Giving a high quatity education, certainly, means to make a big } \\
\text { budget in education. As a result, the institution has to make a big budget in it. To } \\
\text { alocate this big budget, all elements in this institution has to think realistic to find a } \\
\text { real number of this budgets. Beside of } 20 \% \text { of the total budget (APBN) for the } \\
\text { national goal of a high quality education, they have to earn money from other bussiness } \\
\text { for helping institution needs. As the educational insttutions, schools (madrasah) also } \\
\text { have to respond and contribute intellectually to the national education. They must } \\
\text { share the responsibility to realize a high quality of their nation education, so that the } \\
\text { can be give a high quality to their alumnus. }\end{array}$ \\
\hline Artikel Info & Abstrak \\
\hline $\begin{array}{l}\text { Kata kunci: } \\
\text { Anggaran; } \\
\text { Kualitas Manusia; } \\
\text { Sumber daya; } \\
\text { Lembaga; } \\
\text { Bisnis. }\end{array}$ & $\begin{array}{l}\text { Kemajuan suatu lembaga dapat diukur dari kualitas dan kemajuan seluruh unit yang } \\
\text { berada di bawahnya. Sumber daya manusia dan sumber daya manusia dalam suatu } \\
\text { organisasi atau lembaga ditentukan oleh kualitas pendidikan sumber daya } \\
\text { manusianya. Oleh karena itu, lembaga ini memiliki tugas untuk memberikan sistem } \\
\text { pendidikan yang menjamin semua warga negara termasuk semua sumber daya } \\
\text { manusia yang terlibat dalam lembaga tersebut untuk mendapatkan pendidikan yang } \\
\text { berkualitas tinggi. Menyelenggarakan pendidikan yang bermutu tentunya berarti } \\
\text { menganggarkan anggaran yang besar dalam bidang pendidikan. Akibatnya, lembaga } \\
\text { harus membuat anggaran besar di dalamnya. Untuk mengalokasikan anggaran sebesar } \\
\text { ini, semua elemen di lembaga ini harus berpikir realistis untuk menemukan jumlah } \\
\text { anggaran yang sebenarnya. Selain } 20 \% \text { dari total anggaran (APBN) untuk tujuan } \\
\text { nasional pendidikan berkualitas tinggi, mereka harus mendapatkan uang dari bisnis } \\
\text { lain untuk membantu kebutuhan lembaga. Sebagai lembaga pendidikan, sekolah } \\
\text { (madrasah) juga harus merespon dan berkontribusi secara intelektual terhadap } \\
\text { pendidikan nasional. Mereka harus berbagi tanggung jawab untuk mewujudkan } \\
\text { pendidikan bangsa yang berkualitas, sehingga dapat memberikan kualitas yang tinggi } \\
\text { kepada alumninya. }\end{array}$ \\
\hline
\end{tabular}

\section{PENDAHULUAN}

Mutu pendidikan di Indonesia sampai saat ini masih menjadi "pertanyaan besar" bagi kalangan pemerhati pendidikan mengingat masih rendahnya mutu pendidikan kita dibanding dengan negara-negara berkembang lainnya, seperti Malaysia dan Singapura. Demikian pula tingkat pemerataan mutu pendidikan sekolah dan madrasah secara nasional masih memperlihatkan perbedaannya yang cukup tajam, antara sekolah di kota besar dengan sekolah yang berada di pedcsaan, ditambah lagi fakta sosial menunjukkan masih rendahnya tingkat kemampuan ekonomi masyarakat untuk bisa mempe- roleh pendidikan yang layak dan bermutu bagi anaknya, sehingga hal ini mengesankan bahwa kebijakan pemerintah di sektor pendidikan belum memihak kepada rakyat.

Munurut analisis Sandiyawan Sumardi, pada akhir dasawarsa ini, pendidikan di Indonesia menghadapi tiga tantangan besar. Pertama, sebagai akibat krisis ekonomi, pendidikan nasional dituntut untuk dapat mempertahankan hasil-hasil pembangunan pendidikan yang telah dicapai. Kedua untuk mengantisipasi era globalisasi, pendidikan nasional dituntut untuk mempersiapkan sumber daya manusia yang kompeten agar mampu bersaing dalam pasar 
kerja global. Ketiga, sejalan dengan diberlakukannya otonomi daerah, perlu dilakukan perubahan dan penyesuaian sistem pendidikan nasional sehingga dapat mewujudkan pendidikan yang lebih demokratis, memperhatikan keberagaman kebutuhan, keadaan daerah, dan peserta didik, serta mendorong partisipasi masyarakat.

Pada saat yang bersamaan pula, dunia pendidikan nasioanl juga masih dihadapkan pada beberapa permasalahan mendasar yaitu: a) masih rendahnya pemerataan memperoleh pendidikan; b) masih rendahnya kualitas dan relevansi pendidikan; dan c) masih lemahnya manajemen pendidikan, di samping belum terwujudnya kemandirian dan keunggulan ilmu pengetahuan dan teknologi di kalangan akademis, dengan demikian kualitas pendidikan di Indonesia masih memprihatinkan.

Biaya pendidikan merupakan salah satu komponen masukan instrumental yang sangat penting dalam penyelenggaraan pendidikan. Dalam setiap upaya pencapaian tujuan pendidikan, baik tujuan yang bersifat kuantitatif maupun kualitatif, biaya pendidikan memiliki peranan yang sangat menentukan. Ada dua hal penting yang perlu dikaji atau dianalisis dalam pembiayaan pendidikan, yaitu biaya pendidikan secara keseluruhan (total cost) dan biaya satuan persiswa (unit cost) baik yang bersumber dari pemerintah, orang tua, maupun masyarakat yang dikeluarkan untuk menyelenggarakan pendidikan dalam satu tahun pelajaran. Biaya satuan per siswa merupakan ukuran yang menggambarkan seberapa besar uang yang dialokasikan sekolah secara efektif untuk kepentingan siswa dalam menempuh pendidikan. Oleh karena biaya satuan ini diperoleh dengan memperhitungkan jumlah siswa pada masing-masing sekolah, maka ukuran biaya satuan dianggap standard dan dapat dibandingkan antara sekolah yang satu dengan yang lainnya. Selain itu juga biaya yang dikeluarkan oleh siswa disebut juga biaya pribadi (private cost) atau biaya personal (personal cost) meliputi SPP (sebagai konsekuensi keberadaan sekolah swasta), sedangkan biaya satuan pendidikan meliputi uang transport, pakaian seragam sekolah, alat tulis, buku dan alat pelajaran, konsumsi, akomodasi.

\section{METODE PENELITIAN}

Jenis penelitian yang digunakan dalam penelitian ini adalah penelitian kepustakaan atau library research, yakni penelitian yang dilakukan melalui mengumpulkan data atau karya tulis ilmiah yang bertujuan dengan obyek penelitian atau pengumpulan data yang bersifat kepustakaan, atau telaah yang dilaksanakan untuk memecahkan suatu masalah yang pada dasarnya tertumpu pada penelaahan kritis dan mendalam terhadap bahan-bahan pustaka yang relevan. Sebelum melakukan telaah bahan pustaka, peneliti harus mengetahui terlebih dahulu secara pasti tentang dari sumber mana informasi ilmiah itu akan diperoleh. Adapun beberapa sumber yang digunakan antara lain; buku-buku teks, jurnal ilmiah, referensi statistik, hasil-hasil penelitian dalam bentuk skripsi, tesis, desertasi, dan internet, serta sumber-sumber lainnya yang relevan, Dilihat dari sifatnya, maka penelitian ini termasuk penelitian deskriptif, penelitian deskriptif berfokus pada penjelasan sistematis tentang fakta yang diperoleh saat penelitian dilakukan.

\section{HASIL DAN PEMBAHASAN}

\section{A. Biaya Pendidikan}

Berbicara tentang mutu pendidikan dalam perspektif manajemen pendidikan, maka pembiayaan pendidikan merupakan salah satu komponen masukan instrumen (instrumental input) yang sangat penting dalam penyelenggaraan pendidikan khususnya di sekolah / madrasah), dalam setiap upaya pencapaian tujuan pendidikan, baik tujuantujuan yang bersifat kuantitatif maupun kualitatif, biaya pendidikan mempunyai peranan yang sangat menentukan. Hampir tidak ada upaya yang dapat mengabaikan peranan biaya, sehingga dapat dikatakan bahwa tanpa biaya, proses pendidikan (di sekolah/madrasah) tidak berjalan. Biaya (cosfy) dalam pengertian ini memiliki cakupan yang luas, yakni semua jenis penyelenggaraan yang berkenaan dengan semua jenis penyelenggaraan pendidikan, baik dalam bentuk uang, barang dan tenaga yang dapat diuangkan. Dalam pengertian ini misalnya, iuran siswa adalah jelas merupakan biaya, tetapi semua sarana fisik, baik sekolah maupun guru juga adalah biaya.

Mulyasa menegaskan, bahwa biaya merupakan salah satu sumber daya yang secara langsung menunjang efektivitas dan efisiensi pengelolaan pendidikan, hal ini akan lebih terasa lagi dalam implementasi otonomi sekolah yang menuntut kemampuan sekolah untuk merencanakan, rnelaksanakan dan mengevaluasi serta mempertanggungjawabkan pengelolaan dana secara transparan, baik kepada masyarakat maupun pemerintah. 
Dalam penyelenggaraan pendidikan, sumber dana merupakan bagian yang tak terpisahkan dalam kajian pengelolaan pendidikan/ UU No. 20 Tahun 2003 tentang Sistem Pendidikan Nasional lebih lanjut telah mengatur beberapa pasal yang menjelaskan pendanaan pendidikan yaitu pada Pasal 11 Ayat 2 Pemerintah dan Pemerintah Daerah wajib menjamin tersedianya dana guna terselenggaranya pendidikan bagi setiap warga negara yang berusia tujuh sampai lima belas tahun. Lebih lanjut pada Pasal 12, Ayat (1) disebutkan bahwa setiap peserta didik pada setiap satuan pendidikan berhak mendapatkan beasiswa bagi yang berprestasi yang orangtuanya tidak mampu membiayai pendidikannya dan mendapatkan biaya pendidikan bagi mereka yang orangtuanya tidak mampu membiayai pendidikannya. Disamping itu disebutkan pula bahwa setiap peserta didik berkewajiban ikut menanggung biaya penyelenggaraan pendidikan, kecuali bagi peserta didik yang dibebaskan dari kewajiban tersebut sesuai dengan peraturan perundang-undangan yang berlaku. Secara umum pembiayaan pendidikan adalah sebuah kompleksitas, yang di dalamnya akan terdapat saling keterkaitan pada setiap komponennya, yang memiliki rentang yang bersifat mikro (satuan pendidikan) hingga yang makro (nasional). Sumber-sumber pembiayaan pendidikan meliputi sistem dan mekanisme pengalokasiannya, efektivitas dan efisiensi dalam penggunaanya, akuntabilitas hasilnya yang diukur dari perubahan-perubahan yang terjadi pada semua tataran, khususnya sekolah, dan permasalahan - permasalahan yang masih terkait dengan pembiayaan pendidikan, sehingga diperlukan studi khusus untuk lebih spesifik mengenai pembiayaan pendidikan ini, dalam rangka upaya peningkatan mutu pendidikan serta implementasi prinsip efektivitas, efisiensi, transparansi, dan akuntabilitas dalam penyelenggaraan pendidikan, maka studi mengenai perhitungan satuan biaya pendidikan merupakan suatu keniscayaan bagi sebuah institusi.

\section{B. Standar Biaya Pendidikan}

Mengacu pada PP No. 19/2005 Pasal 62 yang menegaskan tentang standar pembiayaan yang akan diatur lebih rinci dalam Peraturan Menteri Pendidikan Nasional, hal ini menjadi makin mendesak dan strategis karena adanya tuntutan terhadap peningkatan mutu pendidikan yang berimplikasi pada kenaikan biaya pendidikan. Sebagai contoh pada tahun pelajaran 2011 / 2012 di beberapa sekolah di Denpasar biaya pendidikan relatif tinggi, hal ini sebanding dengan fasilitas yang disediakan dengan prinsip penerapan proses pembelajaran yang berkualitas tinggi. Hal ini juga terjadi di ibu kota DKI Jakarta dan beberapa tahun belakangan ini diikuti oleh daerah-daerah diseputar Jakarta seperti Depok dan Tanggerang Selatan, maka peran dari aspirasi pendidikan siswa, orang tua siswa maupun masyarakat umum sangat diperlukan untuk mencapai tujuan pendidikan nasional. Keterlibatan siswa, orang tua siswa, masyarakat dan segenap pelaku pendidikan sebagai pendukung dari pendidikan memiliki peran yang vital dalam usaha untuk memberikan aspirasi dalam memajukan sistem pendidikan. Aspirasi ini akan menjadi cermin bagi para pelaku pendidikan untuk lebih menumbuhkan sekaligus mengembangkan kualitas sumber daya manusia. Aspirasi pendidikan siswa dalam rangka meningkatkan kualitas pembelajaran merupakan input yang sangat penting, karena informasi dan motivasi dalam rangka meningkatkan kualitas pembelajaran bersumber langsung dari siswa. Dimana siswa secara langsung menjalani proses pembelajaran tersebut, sehingga siswa dapat menilai perfomance guru dalam proses pembelajaran yang nantinya sebagai bahan masukkan untuk peningkatan mutu pendidikan, selain itu juga aspirasi pendidikan siswa merupakan harapan siswa untuk kelangsungan pendidikan saat ini, pendidikan lanjut dan ekspektasi karir yang menjadi acuan aspirasi guna meningkatkan kemajuan pendidikan.

Disisi lain, masih minimnya akses masyarakat, terutama masyarakat bawah untuk bisa memperoleh layanan pendidikan yang bermutu bagi anak-anaknya, sebagai akibat dari kurangnya komitmen pemerintah dan rendahnya tingkat ekonomi masyarakat, sehingga mereka tidak mampu menyekolahkan anaknya ke sekolah-sekolah yang bermutu, padahal, jika ditilik dari hak memperoleh pendidikan sebagai hak asasi bagi setiap warga negara, maka pemerintah dalam hal ini berkewajiban untuk menyediakan fasilitas dan pendanaannya bagi pendidikan yang bermutu, paling tidak saat ini 
pemerintah baru terfokus pada pendidikan dasar (SD/MI dan SMP/MTs). Undang-Undang Nomor 20 Tahun 2003 tentang Sistem Pendidikan Nasional mengamanatkan bahwa, setiap warga negara yang berusia 7-15 tahun wajib mengikuti pendidikan dasar. Konsekuensi dari amanat undang-undang tersebut, pemerintah wajib memberikan layanan pendidikan bagi seluruh peserta didik pada tingkat pendidikan dasar (SD/MI dan SMP/MTs) serta satuan pendidikan yang sederajat, signifikansi dalam masalah ini adalah apakah target pendidikan untuk semua (Education For All) bisa terwujud.

\section{Pendidikan Bermutu}

1) Pengertian Pendidikan Bermutu

Pengertian mutu dapat dilihat dari dua sisi, yaitu segi normatif dan segi deskriptif. Dalam arti normatif, mutu ditentukan berdasarkan pertimbangan instrinsik dan ekstrinsik. Berdasarkan kriteria intrinsik, mutu pendidikan merupakan produk pendidikan yakni manusia yang terdidik sesuai standar ideal, sedangkan berdasarkan kriteria ekstrinsik, pendidikan merupakan instrumen untuk mendidik tenaga kerja yang terlatih. Adapun dalam arti deksriptif, mutu ditentukan berdasarkan keadaan senyatanya misalnya hasil tes prestasi belajar, dengan demikian, mutu pendidikan adalah derajat keunggulan dalam pengelolaan pendidikan secara efektif dan efisien untuk melahirkan keunggulan akademis dan ekstra kurikuler pada peserta didik yang dinyatakan lulus untuk satu jenjang pendidikan atau menyelesaikan pembelajaran tertentu.

2) Komponen Pendidikan Bermutu

Komponen yang terkait dengan mutu pendidikan adalah pertama, kesiapan dan motivasi siswa. Kedua, kemampuan guru profesional dan kerjasama dalam organisasi sekolah. Ketiga, kurikulum meliputi relevansi isi dan operasional proses pembelajarannya, Keempat, sarana dan prasarana meliputi kecukupan dan keefektifan dalam mendukung proses pembelajaran, Kelima, partisipasi masyarakat (orang tua, pengguna lulusan dan perguruan tinggi) dalam pengembangan program-program pendidikan sekolah.

3) Pendekatan Mutu Pendidikan Pendekatan yang perlu diperhatikan dalam peningkatan mutu pendidikan yaitu:
Pertama, perbaikan secara terusmenerus (continuous improvement). Konsep ini mengandung pengertian bahwa pihak pengelola senantiasa melakukan berbagai perbaikan dan peningkatan secara terus menerus untuk menjamin semua komponen penyelenggara pendidikan telah mencapai standar mutu yang telah ditetapkan. Konsep ini senantiasa memperbaharui proses pendidikan berdasarkan kebutuhan dan tuntutan pelanggan. Jika tuntutan dan kebutuhan pelanggan berubah, maka pihak pengelola institusi pendidikan dengan sendirinya akan merubah mutu, serta selalu memperbaharui komponen produksi atau komponen-komponen yang ada dalam institusi pendidikan.

Kedua, menentukan standar mutu (quality assurance). Paham ini digunakan untuk menetapkan standar-standar mutu dari semua komponen yang bekerja dalam proses produksi atau transformasi lulusan institusi pendidikan, standar mutu pendidikan misalnya dapat berupa pemilikan atau akuisisi kemampuan dasar pada masing-masing bidang pembelajaran, dan sesuai jenjang pendidikan yang ditempuh. Selain itu, pihak manajemen juga harus menentukan standar mutu materi kurikulum dan standar evaluasi yang akan dijadikan sebagai alat untuk mencapai standar kemampuan dasar. Standar mutu proses pembelajaran harus pula ditetapkan, dalam arti bahwa pihak manajemen perlu menetapkan standar mutu proses pembelajaran yang diharapkan dapat berdaya guna untuk mengoptimalkan proses produksi dan untuk melahirkan produk yang sesuai, yaitu yang menguasai Marsus Suti, Strategi Peningkatan Mutu di Era Otonomi Pendidikan standar mutu pendidikan berupa penguasaan standar kemampuan dasar. Pembelajaran yang dimaksud sekurangkurangnya memenuhi karakteristik; menggunakan pendekatan pembelajaran pelajar aktif (student active learning), pembelajaran kooperatif dan kolaboratif, pembelajaran konstruktif, dan pembelajaran tuntas (master learning).

Ketiga, perubahan kultur (change of culture). Konsep ini bertujuan membentuk budaya organisasi yang menghargai mutu dan menjadikan mutu sebagai orientasi 
semua komponen organisasi. Jika manajemen ini ditetapkan di institusi pendidikan, maka pihak pimpinan harus berusaha membangun kesadaran para anggotanya, mulai dari pemimpin, staf, guru, siswa, dan berbagai unsur terkait, seperti pemimpin yayasan, orang tua, dan para pengguna lulusan pendidikan akan pentingnya mempertahankan dan meningkatkan mutu pembelajaran, baik mutu hasil maupun proses pembelajaran.

Keempat, perubahan organisasi (upsidedown organization). Jika visi dan misi, serta tujuan organisasi sudah berubah atau mengalami perkembangan, maka sangat dimungkinkan terjadinya perubahan organisasi, perubahan organisasi ini bukan berarti perubahan wadah organisasi, melainkan sistem atau struktur organisasi yang melambangkan hubungan-hubungan kerja struktur organisasi dan pengawasan dalam organisasi, perubahan ini menyangkut perubahan kewenangan, tugas-tugas dan tanggung jawab, misalnya, dalam kerangka manajemen berbasis sekolah, struktur organisasi dapat berubah terbalik dibandingkan struktur konvensional. Jika dalam struktur konvensional berturutturut dari atas ke bawah; senior manager, middle manager, teacher dan support staff; sedangkan struktur yang baru, berupa struktur organisasi layanan dari atas kebawah berturut-turut; learner, team, teacher and support, staff, dan leader.

Kelima, mempertahankan hubungan dengan pelanggan (keeping close to the costumer). Karena organisasi pendidikan menghendaki kepuasan pelanggan, maka perlunya mempertahankan hubungan baik dengan pelanggan menjadi sangat penting. Dan inilah yang dikembangkan dalam unit public relations. Berbagai informasi antara organisasi pedidikan dan pelanggan harus terus-menerus dipertukarkan, agar institusi pendidikan senantiasa dapat melakukan perubahan-perubahan atau improvisasi yang diperlukan, terutama berdasarkan perubahan sifat dan pola tuntutan serta kebutuhan pelanggan. Bukan hanya itu, pelanggan juga diperkenankan melakukan kunjungan, pengamatan, penilaian dan pemberian masukan kepada institusi pendidikan. Semua masukan itu selanjutnya akan diolah dalam rangka mempertahankan dan meningkatkan mutu proses dan hasil-hasil pembelajaran. Dan yang perlu diperhatikan adalah bahwa dalam manajemen berbasis sekolah, guru dan staf justru dipandang sebagai pelanggan internal, sedangkan pelajar, termasuk orang tua pelajar dan masyarakat umum, termasuk pelanggan eksternal. Maka, pelanggan baik internal maupun eksternal harus dapat terpusatkan melalui interval kretaif pimpinan institusi pendidikan.

\section{Prioritas Alokasi Pendidikan yang Berorientasi Pada Mutu}

Tidak dipungkiri bahwa mutu pendidikan sangat terkait erat dengan anggaran pendidikan yang dialokasikan, dalam perspektif ekonomi pendidikan biaya pendidikan mencakup biaya langsung (oleh sekolah, peserta didik, atau keluarga peserta didik), dan biaya tidak langsung (seperti inkaminkam yang dilewatkan), pada kenyataannya, biaya pendidikan lebih dicurahkan pada biaya-biaya langsung, karena akibat-akibat dari biaya langsung dirasakan langsung dan kuat oleh pembayar beban pendidikan pemerintah dan masyarakat, pada umumnya biaya langsung ditanggung oleh pemerintah dan masyarakat yang berkaitan dengan sistem-sistem sekolah. Aspek penting yang perlu diperhatikan terkait dengan pengelolaan pembiayaan pendidikan adalah: (1) memprediksi kebutuhan pendidikan; (2) alokasi setiap komponen biaya; (3) analisis sumber, dari mana dana dapat diperoleh; dan (4) pengawasan keuangan; cocok tidak antara perencanaan dan penggunaan anggaran.

Sebagai catatan kritis, sistem penganggaran pendidikan di Indonesia menurut Clark (1998:25) sangat rumit, dan di sana tidak terdapat mekanisme yang teratur untuk mendapatkan gambaran yang utuh mengenai pembiayaan sekolah atau membandingkan perbedaan biaya-biaya antar jenjang pendidikan, tidak ada data komprehensif mengenai biaya dan penganggaran pendidikan disekolah dan masyarakat sebagai bahan bagi pemerintah dalam mengembangkan dan menentukan kerangka kebijakan mobilisasi, alokasi sumber-sumber, dan efektivitas penggunaan biaya pendidikan.

Oleh sebab itu tidak mengherankan ketika banyak kasus di sekolah yang mengandalkan pembiayaan sekolah dengan menarik dana yang sangat besar kepada masyarakat. Apalagi 
dengan berlindung kepada konsep MBS dan otonomi sekolah yang sekarang sedang menjadi kebijakan pendidikan nasional kita, seakan sekolah memperoleh legitimasinya untuk menarik dana masyarakat untuk pembiayaan pendidikan. Di sinilah peluang terjadinya komersialisasi pendidikan dengan berbagai alasan:

Pertama, subsidi pemerintah untuk biaya operasional sekolah sangat terbatas sehingga tidak mungkin mengandalkan dana sepenuhnya dari pemerintah, sementara kebutuhan sekolah dan tuntutan mutu pendidikan memerlukan dana yang tidak sedikit.

Kedua, konsep MBS yang berbasis otonomi sekolah memungkinkan pihak sekolah secara mandiri untuk mencari dana dan mengelolanya. Apalagi jika kerangka MBS tidak dipahami oleh pengelola pendidikan secara benar, maka pemungutan dana dilakukan menurut keinginan sekolah untuk biaya operasional pendidikan tanpa batas kewajaran. Orang tua siswa sebagai unsur masyarakat yang berhubungan langsung dengan sekolah akan menjadi sasaran pertama dalam pendanaan.

Ketiga, tidak adanya standarisasi penarikan biaya pendidikan dari dinas terkait, membuka peluang bagi sekolah melakukan pungutan secara liar (bebas). Sebagai akibatnya, sekolah-sekolah "mahal" yang menjual "mutu" hanya dapat dijangkau oleh sekolompok kecil masyarakat. Hal ini juga sebenarnya mengingkari garis kebijakan pendidikan kita yaitu pendidikan untuk semua (education for all) dan tidak sejalan dengan semangat demokrasi pendidikan.

\section{SIMPULAN}

Dalam pengelolaan penyelenggaraan pendidikan, sumber dana merupakan hal yang tak mungkin tertolak, dana tersebut dapat bersumber dari pemerintah ataupun dari usaha lembaga pendidikan yang dilaksanakan secara mandiri. Semua itu bertujuan agar diperoleh mutu lembaga pendidikan yang dapat memenuhi standar harapan masyarakat, kritik rendahnya mutu pendidikan merupakan fakta sosial yang tidak dapat dipungkiri, situasi dan kondisi perekonomian yang unstable yang saat ini menjadi persoalan yang tidak dapat dianggap ringan disebabkan oleh situasi politik yang tidak kondusif terpengaruh kondisi ekonomi dan politik dunia.

Untuk mencapai mutu pendidikan yang sesuai dengan harapan masyarakat tersebut diatas perlu ditopang dengan peningkatan biaya pada lembaga pendidikan tersebut, pembiayaan ini dapat berupa pembiayaan mandiri dan akuntabel yang dikelola langsung oleh lembaga dengan memberdayakan unsur-unsur masyarakat sekolah, apalagi jika ditopang oleh sistem Total Quality Manajemen yeng diterapkan dalam usaha seperti Koperasi Serba Usaha yang tentunya akan mendatangkan benefit yang secara langsung akan berimbas kepada peningkatan mutu sekolah. Mutu pendidikan yang dapat melahirkan lulusan dan alumni yang siap pakai serta generasi baru kedepan yang dapat mengangkat wibawa bangsa dimata dunia.

\section{DAFTAR RUJUKAN}

Arikunto, Suharsimi. 2010. Prosedur Penelitian: Suatu Pendekatan Praktik. Jakarta: Rineka Cipta.

Ascarya. 2007. Akad \& Produk Bank Syariah. Jakarta: PT RajaGrafindo Persada.

Bungin, Burhan. 2013. Metodologi Penelitian Sosial dan Ekonomi. Jakarta: Kencana Prenamedia Group.

Dedi Supriadi, Saluran Biaya pendidikan dasar dan Menengah, Bandung: Remaja Rosdakarya, 2003, hal. 4

Mauk Pajar, Hotistika Pemkiran Pendidikan, Qabrta: PT. Raja Grafika Petsada, 2005), hal. 251-253

Mulyasa, Manajemen Berbasis Sekolah @Bandung: Remaja Rosdakarya, 2002), hal. 167.

Sandiyawan Sumardi, Melawan Stigma Melalui Pendidikan Alternatif (Jakarta: Grasindo: 2005), hal. 51

Syaiful Sagala, Manajemm Strategi dalam Peningkatan Mutu Pendidikan: Pembuka Ruang Kreativitas, inovasi dan Ptmberdayaan Potensi Sekalab dalam Sistem otonomi Sekolah mengandung: Alfabeta, 2007), haI. 209. 